\title{
TOWARDS THE HARMONISATION OF REASON AND REVELATION IN EDUCATION
}

\author{
Abdul Karim Abdullah*
}

\begin{abstract}
With the emergence of empiricism, a perception developed that rationality and faith are 'incompatible.' According to this view, religion is based on faith rather than knowledge. Attachment to faith is fundamentally arbitrary and lacks a rational foundation. In education, the 'separation' of reason from faith produces either graduates with knowledge for the purpose of employment but little spiritual awareness or persons with religious beliefs that have few marketable skills. What is required is balanced education, where instruction in revealed knowledge is provided together with training in present-day knowledge. To facilitate holistic education, it is necessary to recognise that faith and present-day knowledge complement rather than exclude each other. Present-day knowledge is used primarily for the purpose of employment. Revealed knowledge is intended for the purpose of guidance. The two are complementary rather than mutually exclusive.
\end{abstract}

Keywords: knowledge, Qur'an, rationality, ijtihad, taqlid.

\section{Introduction}

The fulfilment of material and religious requirements facilitates the realisation of one's potential. This entails the utilisation of revealed as well as empirically acquired knowledge. Rationality may be understood as the use of reason ('aql) to understand reality. ${ }^{1}$ Revelation, by contrast, is knowledge relayed by God's messengers, the prophets. ${ }^{2}$

While the attainment of both kinds of knowledge requires the use of 'reason', reason alone is ill-equipped to attain the kind of knowledge provided by revelation. Thus, to 'understand' revelation fully, as it were, a 'leap of faith' is required in addition to a rational comprehension of the message of revelation. In different words, the 'bigger picture' has to be grasped intuitively.

Nonetheless, empirical perception provides the necessary beginning point on the journey to religious awareness. The 'signs' (ayat) of God that serve as 'guideposts' first have to be perceived. These 'signs' have to be pondered by the intellect. ${ }^{3}$ This pondering, however, takes place in the 'heart,' which may be understood to encompass rational understanding aided by intuition. 


\section{Reason and Revelation}

Revelation presents itself as a divine message. It addresses itself to humankind. Revelation is brought by the messengers of God. It teaches the difference between good and evil. Reason enables us to understand revelation.

The alleged 'incompatibility' between reason and revelation forces a person to 'follow' either reason or revelation. ${ }^{4}$ This hampers persons with a predisposition for reason from accepting faith, while discouraging religious persons from acquiring present-day knowledge. Thus, persons leaning towards rationality tend to remain unaware of revealed knowledge, while religious persons tend to have little interest in acquiring knowledge of current disciplines.

At the psychological level, having to 'follow' either reason or revelation results in a 'separation' within a person between his or her spiritual and physical existence. To heal this 'dividedness,' it needs to be recognised that religious awareness is far from 'irrational,' but is indispensable to a meaningful existence. $^{5}$

From the perspective of revelation, attaining and following revealed knowledge is a rational act. ${ }^{6}$ The alleged exclusivity of reason and revelation is therefore a false dichotomy. Indeed, attaining faith is hardly possible without the use of reason. The relationship between reason and revelation is "complementary rather than contradictory." "

At a basic level, epistemic reconciliation between reason and revelation may be achieved by acknowledging that the two represent different aspects of reality. When properly integrated, they work together. Empirical knowledge assists us in 'cultivating the earth,' while revealed knowledge provides guidance.

A different way of looking at the relationship between empirical and religious knowledge is to realise that present-day knowledge and the knowledge of revelation are fundamentally different kinds of knowledge. ${ }^{8}$ The former is descriptive, while the latter is prescriptive. Revealed knowledge has a moral aspect that is absent from empirical knowledge. ${ }^{9}$

The perception that reason and revelation are "irreconcilable" stems from different assumptions regarding existence and the way in which we attain knowledge. The perspective of the empiricist is restricted to the realm of perception. To the empiricist, "seeing is believing." 10 The perspective of the believer, by contrast, allows for the possibility of events that may appear 'inexplicable,' if viewed from an 'empirical' perspective. The viewpoint of the believer, we might say, 'transcends' the perspective of the empiricist.

Revealed knowledge provides answers to queries that the empirical method is unable to answer, as empirical knowledge is limited to the realm of experience. The empirical approach, in particular, is not equipped to distinguish between 
'right' and 'wrong,' as it only describes what is; it is not able to prescribe what ought to be. Religion by contrast differentiates between what is and what ought to be.

'Prescribing,' as distinguished from 'describing,' requires awareness of the difference between the ideal and the actual. The gap between the two, if any, is a reflection of a person's achievement. Religion exhorts humanity to believe and act in agreement with revealed knowledge. It provides guidance on the rank of values. The Shari'ah supplies the elaboration of the do's and don'ts for life.

\section{Rise of Taqlid and the Atrophy of Rationality}

Reason is the faculty of understanding. Thus, we speak of the "power of reasoning" and of the "power of speech." The use of reason is indispensable in everyday life. Existence without the use of reason would be difficult, to say the least.

The use of reason is particularly indispensable in acquiring knowledge. All sciences are developed, to a greater or lesser degree, by reasoning. It is by means of reasoning that we determine the probable effects of various causes and actions. Reasoning helps man to take responsibility for his actions.

Reasoning takes various forms, including deductive, inductive, analogical, and intuitive. Reasoning is used for differentiating truth from falsehood and understanding revealed guidance.

An important difference exists between a person who uses his reason and a person who does not or is unable to do so. People do not use their reason have to be placed under supervision, as they might present a threat to themselves as well as other people.

Islam appears to have exhibited what may be termed a 'tension' between rationality and revelation. The period of the Golden Age of Islam exhibited a concord between reason and revelation. ${ }^{11}$ The Islamic civilisation blossomed:

As Europe was plunged into the Dark Ages, the Arab-Islamic world experienced its Golden Age; illustrious centers of learning in Baghdad, Cairo, Palermo, Cordova, Granada, Seville and Toledo drew scholars from far and wide, who not only studied the works of the Ancients but also developed bodies of Arab-Islamic science and philosophy. This westward flow of ideas and practices profoundly shaped Europe's development. ${ }^{12}$

During this period, Muslims were willing to obtain and utilise knowledge from different parts of the world. ${ }^{13}$ In subsequent eras, however, the balance between reason and revelation appears to have been altered. 
A growing focus on tradition had the effect of gradually marginalising reason. This was particularly apparent in legal thinking that was:

characterized by the institutionalization of the dominant schools, with emphasis not on new developments but on following precedent (taqlid) ... Original thinking and direct recourse to the sources of the Shariah, which had characterized the first three centuries of development, were no longer encouraged ... Imitation and following precedent thus gained ground, and the so-called 'closure of the gate of ijtihad' followed. ${ }^{14}$

Independent reasoning was gradually replaced by adherence to tradition, known as taqlid. ${ }^{15}$ The latter required accepting and abiding by time-honoured explanations of the revealed text. ${ }^{16}$ There was limited space for dissenting opinions.

A factor that facilitated the rise of taqlid was the view that the early Muslims had a better understanding of Islam than the following generations, that subsequent events amounted to a descent from the Golden Age of Islam. ${ }^{17}$ In addition, the adoption of taqlid was justified by the perception that all 'problems' had been addressed, therefore making further ijtihad redundant: ${ }^{18}$

The persistent decline of critical reason among Muslims is due partly to the notion that the exercise of ijtihad ceased with the epochmaking works of the legists of the past. Added to this is the prevailing mindset that a Muslim should follow one or the other of the established madhhabs and abandon his judgment in favour of interpretations of earlier centuries even though their originators could have no knowledge of the needs and challenges facing twenty-first century Muslims. ${ }^{19}$

The emergence of taqlid began with the struggle between the "rationalists" and "traditionalists," the jurists of Iraq and Medina. ${ }^{20}$ "Classical Islamic tradition recognised the two sides of the debate as being constituted of the ahl alhadith (people of prophetic 'tradition') and the ahl al-ra'y (people of reason), respectively." 21

The adherents of tradition "preferred not to rely on human reason and chose instead to base their doctrines as much as possible on the precedents established in the Qur'an and the hadith." 22 In other words, the "Traditionists relied mainly on textual authority and were averse to the use of personal opinion $\left(r a^{\prime} y\right)$...the Rationalists were inclined, in the absence of a clear text, toward a more liberal use of personal reasoning." ${ }^{23}$

The first two centuries of the Abbasid era $(750$ - 950) were known as the "era of independent reasoning." ${ }^{24}$ With the ascension of the seventh Abbasid caliph, al-Ma'mun, in 813, the rationalists prevailed. The advocates of rationalism, however, fell from grace under al-Mutawakkil (d.861). ${ }^{25}$ 


\section{Effects of taqlid}

With the emergence of taqlid, restrictions were imposed upon reason - juristic reasoning or ijtihad in particular - in the name of methodology and related concerns. Ijtihad was first restricted to analogical reasoning (qiyas), before being prohibited altogether. In this way, the "doors to ijtihad" were shut. ${ }^{26}$

In general, taqlid "advanced an attitude of extreme caution and conservatism in the expression of opinions on religious issues. As a result, ijtihad suffered." 27 Following a literal approach became widespread. Expression of personal views was frowned upon. It almost appeared as if a reluctance to refrain from using reason was a mark of piety.

Many orthodox Islamic scholars went to the extreme of denying reason and its role, thus limiting Islamic thought to literalist and descriptive studies of the revealed texts that have continued to influence Islamic thought by making it suspicious even today of all forms of rational inquiry. ${ }^{28}$

As another writer put it: "traditionalists...did not want to use any type of human reasoning in law and instead preferred to base every single case on the doctrine of tradition, even if it was weak." 29 Appeals to tradition were favoured at the expense of appeals to reason. In other words, tradition eclipsed reason as 'authority.' The latter was increasingly viewed as unreliable and prone to error.

Moreover, the declines of reasoning was felt far and wide: "a taqlid-based mentality...incapacitated the Muslim mind so that it was no longer capable of responding satisfactorily to events as they occurred." ${ }^{30}$ The effect of this "denigration of human reason" ${ }^{31}$ was a crisis:

The Muslim mind experienced a crisis of thought when, during the first centuries of the Islamic era, ijtihad began to be viewed as limited to legal matters rather than as a methodology for dealing with all aspects of life...this particularization of ijtihad confined the Muslim mind, and taqlid eventually led to the paralysis of its creative abilities... Had it not been for taqlid and its subduing of the Muslim mind, that mind would have achieved great things. ${ }^{32}$

Another writer put it this way:

Islamic civilization... underwent a moral and intellectual crisis in the $9^{\text {th }}$ to the $11^{\text {th }}$ century of our era, when it turned its back on philosophy and took refuge in dogma...The gates to Ijtihad (independent reasoning) closed. Taqlid (imitation) ruled. Rationality was dead; it was expelled from the syllabus at the al-Azhar until endeavours to restore it in the late $19^{\text {th }}$ century. ${ }^{33}$ 
An open exchange of views is required for any society to flourish. The intellect plays an indispensable part in analysis. But for reason to play its expected role in Islam, it has to be 'rehabilitated' as a faculty of gaining knowledge. Far from being an 'enemy' of revelation, reason is its ally.

Efforts to upgrade the status of reason - and present-day disciplines - within Muslim institutions of learning have already begun. These efforts have to be sustained and enhanced.

Notably, an attempt to revive rational inquiry took place at the turn of the twentieth century, with the works of "modernists" such as Jamal ad-Din alAfghani (d. 1897). ${ }^{34}$ This period was "marked by less emphasis on precedent and greater emphasis on original thinking." ${ }^{35}$ Afghani believed that "The Islamic religion is the closest of religions to science and knowledge, and there is no incompatibility between science and knowledge and [the] foundation of the Islamic faith." ${ }^{36}$ This view was shared by his follower, Muhammad "Abduh (d.1905), as well as reform-minded scholars. ${ }^{37}$

Under Muhammad 'Abduh, al-Azhar University introduced present-day disciplines, such as medicine and foreign languages. In India, Aligarh University was set up to address the requirements of local Muslims for a contemporary integrated curriculum. Even madrassahs were reformed. ${ }^{38}$ In Turkey, schools were set up with a comparable purpose in mind. ${ }^{39}$

A recent reformer was Fazlur Rahman. In 1962, he was appointed by the then President of Pakistan, Ayub Khan, as Director of the Central Institute for Islamic Research. From 1962 to 1968, Fazlur Rahman attempted to reform Islamic tertiary education in Pakistan. His efforts, however, like the efforts of "Abduh at al-Azhar, were resisted by traditional parts of society. ${ }^{40}$

\section{Qur'anic Emphasis on Reason}

The marginalisation of reason, exemplified by the preference for tradition, finds no support in the Qur'an. The holy book uses the term "reason" in a wide sense. It places heavy emphasis on thought, reflection and meditation.

Approximately 750 verses, or nearly one-eighth of the Qur'an, exhort the readers to study nature, history, the Qur'an itself, and humanity at large. The text employs a range of expressions in its appeal to those who listen (yasma'un), those who think, (yatafakkarun), those who reflect (yatadabbarun), those who observe (yanzurun), those who exercise their intellect (ya'qilun), those who take heed and remember (yatadhakkarun), those who ask questions (yas'alun), those who develop an insight (yatafakkahun), and those who know (ya'lamun). These...consist essentially of...encouragement to thinking. ${ }^{41}$ 
The Qur'an frequently refers to the 'signs' (ayat) of God: "On the earth are signs for those of assured Faith, as also in your own selves: will ye not then see?" 42 It also says: "(Here is) a Book which We have sent down unto thee, full of blessings, that they may meditate on its Signs, and that men of understanding may receive admonition." 43

The "signs' of God "require thinking and reflection."44 This means that "faith (iman) and reason ( ' $a q l$ ) go hand in hand. The Qur' an stresses the importance of using science, logic and reason as tools for discovering God. 'Will you not then use your reason?' it asks, again and again." ${ }^{45}$ Multiple verses in the Qur'an:

encourage rational observation, thought and reflection on the observable world and the universe beyond...signifying a rational and inquisitive approach to constructing a worldview of Islam. Islam, in other words, advises analytical knowledge and understanding that generate insight rather than a purely dogmatic approach. ${ }^{46}$

Another commentator put it this way: "reason is the human tool for comprehension.." ${ }^{\prime 7}$ But if knowledge of physical existence is attained by the reason ( $a q l$ ), religious awareness is attained by the heart. The heart may be thought of as a faculty of higher awareness, encompassing both cognition and intuition.

The revealed text frequently exhorts Muslims to guard against unreflective following:48 "When it is said to them: 'Follow what Allah hath revealed,' they say 'Nay! We shall follow the ways of our fathers.' What! Even though their fathers were void of wisdom and guidance?"49 On Judgment Day, the followers will realise their mistake: "And they would say: Our Lord! We obeyed our chiefs and our great ones, and they misled us as to the (right) path." 50

Thus, "[p]eople are...advised to use their own judgment and distinguish between guidance and misguidance in the light of reason. This is because they themselves, and not their self-styled leaders, would ultimately be held responsible." ${ }^{51}$ It is reason, guided by revelation, that enables people to distinguish between truth and falsehood:

It is reason which distinguishes between true wahy [and] false, between misleading lies, fabrications, and myths. Likewise, it is reason which enables humans to choose and face the consequences of the choices they make. ${ }^{52}$

Another commentator put it this way: "The role of sound human intellect ( ' $a q l$ ) is very important in Islamic epistemology to complement divine revelation, and to expand the frontiers of human knowledge in harmony with the truths, values and norms of revelation." ${ }^{53}$ Reason also enables us to tell the difference between the useful and the harmful in everyday existence: 
temporal benefits and harms are mostly known and identified by 'aql, not only in the shari'ah of Islam, but in most other legal traditions. A person of sound judgment would know, even before the existence of a revealed text, that realisation of pure benefit or prevention of pure evil is praiseworthy. The learned in most legal traditions, and all the revealed laws, tend to be in agreement on the prohibition of murder, theft, adultery and the like. ${ }^{54}$

Thus, it is important to recognise the role intellect plays in all walks of existence. It also should be recalled that the protection of the intellect is one of the higher purposes of the Shari'ah.

\section{Reconnecting Thought and Piety}

Various attempts have been made recently to enhance the rank of reason within Islam. Prominent among these is the attempt to include present-day disciplines within Islamic institutions of learning.

However, efforts to integrate present-day knowledge in Islamic education have met with resistance. Those with reservations felt that unfamiliar disciplines should be 'Islamised' before being included in Islamic education. ${ }^{55}$ Another faction of Muslims "tried to identify themselves with a pure, ideal Islam, while at the same time condemning their centrist opponents as impure, deviating Muslims. And in identifying with Scripture, they interpreted this in as literal, and hence as absolutist and exclusivist, a light as possible." ${ }^{56}$ The result was that:

The encounter of the established Islamic schools with new civil schools produced different responses in two main directions: modernist Islamic educators set out to revise their curriculum and make it responsive to the new era by evoking the principle of independent reasoning (ijtihad), sometimes fusing it with secular subjects, whereas their conservative colleagues took to reviving traditional teaching in the spirit of adherence to precedent (taqlid). ${ }^{57}$

To resolve this tension, it is necessary to realise that the pursuit of present-day knowledge does not require a person to abandon or dilute his or her faith. On the contrary, it makes it possible for a person to function better in the presentday milieu. "The nexus between faith and reason...constitutes the hallmark of intelligent Islamic spirituality, wherein human intellect and emotions are guided toward harmony with one another." 58

A basic accord between rationality and revelation means that a person may be a practising Muslim and an educated professional simultaneously. The attainment 
of present-day knowledge is an essential component of a well-rounded education. Reason analyses material provided by perception.

Human intellect ( $a l-{ }^{\prime} a q l$ ) is informed by the senses, but has the capacity to go beyond the data of the senses, although it falls short of the wider reaches of revelation (al-wahy). The intellect...perceives that which is unseen based on that which is seen, derives universals from concrete particulars, recognises self-evident truth, and associates causes and effects...Human reason is therefore a credible basis of judgment in the absence of revelation, provided that the judgment arrived at is in harmony with the general spirit and guidance of the revealed scripture. ${ }^{60}$

Establishing a balanced relationship between rationality and revelation is in keeping with the principle of wasatiyyah. ${ }^{61}$ The anti-rationalist rhetoric of Islamism is alien to the Qur'an. ${ }^{62}$ "Thinking Muslims should work to vindicate the symbiotic relation of faith and reason in their religion and see it as a source of enrichment and contribution of Islam to human understanding and civilisation." $" 63$

Revealed knowledge addresses fundamental questions of existence and establishes the parameters of the knowledge attained by present-day disciplines. Revelation provides answers to queries that reason, due to its shortcomings, is unable to answer:

Wahy or revelation is the divine source which provides man with the knowledge he needs of the unseen world; whereas reason is the instrument man uses to acquire and apply knowledge in this world, which is the seen world, in order to achieve the mission of khilafah and its aims of establishing truth, justice and righteousness. ${ }^{64}$

Revealed knowledge guides the use of empirical knowledge. Where empirical knowledge enhances power, spiritual awareness enables people to apply this influence wisely, i.e., in accord with the teaching of revelation.

\section{Conclusions and Recommendations}

The reconciliation of reason and revelation will require acknowledgment that reasoning is a sine qua non for comprehending revelation. It is important to acknowledge that reason and revelation are compatible despite essentially fulfilling different roles. Present-day studies should demonstrate this, alongside Islamic studies in Muslim institutions of learning. Finally, the paper makes the following recommendations:

- $\quad$ The understanding of ijtihad ought to be wider. 
- The teaching of philosophy and reasoning (logic) ought to be integrated within Muslim educational institutions.

- Textbook writers should write books that are free of taqlid's influences and assumptions, both of which run counter to the teachings of Islam.

- The teaching of religious studies has to be integrated with the teaching of present-day disciplines at all levels.

\section{Notes}

* Abdul Karim Abdullah (Leslie Terebessy), Assistant Fellow at IAIS, earned his MA in political philosophy from the University of Toronto, Canada (1999) and a MEd (1986) from the University of Toronto's Ontario Institute for Studies in Education (OISE). A former lecturer, editor, writer and coordinator of the English programme at University Sains Islam Malaysia (USIM), his current projects involve research into the current financial crisis, critical thinking in Muslim societies, and Islamic Finance. He has edited Islamic Studies at World Institutions of Higher Learning (Kuala Lumpur: USIM 2004). He can be contacted at abdulkarim@iais.org.my.

1. Present-day empirical knowledge is, in effect, a product of 'reason.'

2. The philosophers could be viewed as representing reason while prophets represent revelation.

3. Empiricism and rationalism form the bedrock of present-day epistemological methodologies. The first of these holds that there is no phenomena "beyond" what can be perceived, while the second dictates that all reasoning about any part of reality must proceed in a logical manner. Alternatively expressed, all statements regarding reality need to have a basis in perception while also being free of contradictions and fallacies.

A point of divergence between rationalism and empiricism is that rationalism recognises a priori ideas (those acquired 'prior to' experience or 'innate' ideas), while empiricism does not. In other words, in empiricism all ideas are derived from experience. In principle, Qur'anic epistemology rejects neither empiricism nor rationality. However, it recognises metaphysical knowledge as valid knowledge in addition to knowledge grounded in perception, and asserts that all knowledge must be utilised in ways which accord with revealed knowledge.

4. Thus, persons of faith tend to view rationality with apprehension, while persons with a preference for rationality tend to be reticent regarding faith. This view does not just hinder access to present-day knowledge by persons of faith; it hampers practitioners of present-day subjects from reflecting upon the teachings of revelation.

5. The "dividedness" or the "incompleteness" of man has also been referred to as "alienation." It goes without saying, however, that the way in which this term was understood by Marx, for example, is radically different from a spiritual understanding of it. 
6. A rational act may be defined as one that adds to the preservation and wellbeing of the person or community performing it, without inflicting harm upon any person or persons in the process. A rational act is in accordance with a person's predisposition (fitrah), and takes place without violating anyone's dignity. A rational act is always in harmony with justice.

7. Mohd Farid Mohd Shahran, "Reason and Revelation in Harmony," The Star Online, 28 October 2014, Available at <http://www.thestar.com.my/opinion/ columnists/ikim-views/2014/10/28/reason-and-revelation-in-harmony/> (Accessed on: 7 March 2017).

8. It is unhelpful to maintain, as a few Muslims do, that all knowledge is in the Qur'an. If this were the case, there would hardly be any need for extensive databases of digitally stored material or libraries with tomes of books. It is better to say that all knowledge needed for the purpose of faith is in the Qur'an, as indeed the Qur'an itself asserts (6:38). The idea that there is a "unity" of knowledge hardly signifies that there is just one kind of knowledge. Indeed, different areas of enquiry produce different kinds of knowledge. Nonetheless, all subjects are related to each other, to a greater or lesser degree. Thus, from a general perspective, the realm of epistemology is essentially borderless. This is no doubt among the reasons why reputable universities allow, and even encourage, what is known as "interdisciplinary studies."

9. This does not mean, of course, that the use of empirical knowledge has no moral effects. On the contrary, the application of modern knowledge has many effects, not all of them positive. One example is the de-personalisation of communication due to the widespread use of advanced communication technologies.

10. Expressed alternatively, whatever cannot be perceived has no real existence. Such phenomena may be said to exist "in the mind," which is to say in a person's "imagination" rather than in real existence.

11. Interestingly, partly on account of their alleged excessive emphasis on rationality at the expense of revelation, as well as their insistence that the Qur'an was created, the Mu'tazilites were declared apostates by their adversaries, the traditionalists.

12. Nayef Al-Rodhan 'The Islamic World and the West: Recovering Common History,' YaleGlobal Online, Yale University, 2014. Available at: http:// yaleglobal.yale.edu/content/islamic-world-and-west-recovering-commonhistory (Accessed on: 23 April 2017).

13. Marmaduke Pickthall, 'Causes of the Rise and Decline of Islam,' speech delivered by Marmaduke Pickthall in Madras, India, 1927, Canadian Society of Muslims. Available at http://muslimcanada.org/pickthallrisefall.pdf (Accessed on: 22 April 2017)

14. Mohammad Hashim Kamali 'Law and Society: The Interplay of Revelation and Reason in the Shariah,' in The Oxford History of Islam, ed. John Esposito (New York, Oxford University Press, 1999), 114-5.

15. The Oxford Dictionary of Islam defines taqlid as follows: "Imitation. Conformity to legal precedent, traditional behaviour, and doctrines. Often juxtaposed by reformers with ijtihad, independent reasoning based on revelation. Traditionally, legal precedent is considered binding in Islamic law, but taqlid has acquired a negative connotation among modern reformers, who 
use the term to refer to cultural and intellectual stagnation and unwillingness to experiment with new ideas. Reformist criticism has taken both fundamentalist and modernist directions." N.a. 'Taqlid,' The Oxford Islamic Studies. Available at http://www.oxfordislamicstudies.com/article/opr/t125/e2339 (Accessed on: 27 March 2017).

16. The reverence for past scholars was great. When establishing the Muslim College in the United Kingdom in 1978, noted educationist Zaki Badawi observed: "The plan or the philosophy of the College is to promote critical ability in the service of the study of Islam and to free the discipline from the dominance of past scholars whose authority is elevated in our traditional institutions to the level of the prophet (P.B.U.H) and sometimes even above it." M.A. Zaki Badawi, 'Islamic Studies in British Universities: Challenges and Prospects,' in Islamic Studies in World Institutions of Higher Learning (Bangi: Islamic University College of Malaysia, 2004), 9.

17. It appears a backlash against reason (and empirical knowledge generally) likewise transpired in sixteenth-century Turkey. n.a. 'Discussion: Why did the Islamic World Fail to Achieve the Scientific and Industrial Revolutions? Case in Point: The Story of Takiyuddin Efendi.' Available at: http://phys-sun-1.phys. boun.edu.tr/ semiz/universe/near/04.html (Accessed on: 18 April 2017).

18. Taha J. al 'Alwani, 'Ijtihad,' IIIT, 18. Available at: https://books.google.com. $\mathrm{my} /$ books?hl=en\&lr=\&id=5gNgCgAAQBAJ\&oi=fnd\&pg=PA1\&dq=Alwani + the + crisis + of + fiqh\&ots $=$ AZ WosThAg\&sig=JfisfjzpHFCUDCPJXM7D9gTj CXE\&redir_esc $=y \# v=$ onepage\&q\&f=false (Accessed on: 9 March 2017).

19. Mohammad Hashim Kamali, 'Issues in the Theory of Ijtihad: A Reappraisal,' IAIS Bulletin 29 (2015).

20. For a discussion of the ahl-al hadith and the ahl-al ra'y see Mohammad Hashim Kamali, Principles of Islamic Jurisprudence (Kuala Lumpur: Ilmiah Publishers, 2004), 251-3.

21. Yudian Wahyudi, "The Slogan "Back to the Qur'an and the Sunna": A Comparative Study of the Responses of Hasan Hanafi, Muhammad 'Abid al-Jabiri and Nurcholish Madjid,' Unpublished PhD Thesis, The Institute of Islamic Studies McGill University, Montreal, Canada (2002), 1.

22. Mohammad Hashim Kamali 'Law and Society', 114.

23. Ibid., 112.

24. Ibid., 112.

25. The Abbasid empire collapsed in 1258 as a result of the Mongol conquest. The Ottoman caliphate collapsed in 1924.

26. For a brief treatment regarding the effects of fanaticism upon reason in Islam, c.f. Hashem Saleh, 'Arkoun and the Defeat of Reason in Islam $1 \&$ 2,' AlMuslih.org, Available at: http://www.almuslih.org/index.php?option=com_content\&view =article\&id=276:arkoun-and-the-defeat-of-reason-in-islam\&catid=56:islamand-rationality\&Itemid=245 (Accessed on: 5 April 2017).

27. M. Umer Chapra, Muslim Civilization (Leicester: The Islamic Foundation, 2008), 123.

28. AbdulHamid AbuSulayman, Crisis in the Muslim Mind (Herndon, USA: The International Institute of Islamic Thought, 1993), 40-1.

29. Butti Sultan Butti Ali Al-Muhairy, 'Islamisation and Modernisation within the 
UAE Penal Law: Shari'a in the Pre-Modern Period,'Arab Law Quarterly 10, no. 4 (1995): 299.

30. Taha J. al 'Alwani, 'The Crisis of Fiqh and the Methodology of Ijtihad,' American Journal of Islamic Social Sciences 8, No. 2 (1991): 336.

31. Daniel E. Burns 'Alfarabi and the Creation of an Islamic Political Science,' The Review of Politics 78 (2016): 382.

32. Taha J. al 'Alwani, 'The Crisis of Thought and Ijtihad,' American Journal of Islamic Social Sciences 10, no. 2 (1993): 234.

33. Sabah Mushtaq 'Intellectual Suicide of the Muslim Mind: Recovery of Reason is Imperative for the Muslim Mind to be Successful,' New Age Islam 5 Nov. 2016.

34. For an example of contemporary efforts to revive Islam, see Irfan Ahmad 'Genealogy of the Islamic State: Reflections on Maududi's Political Thought and Islamism,' The Journal of the Royal Anthropological Institute 15 (2009): 145-62.

35. Kamali 'Law and Society', 114-115.

36. Malik Mohammad Tariq, 'Jamal Ad-Din Afghani: A Pioneer of Islamic Modernism,' The Dialogue VI, no. 4: 345.

37. Ahmad N. Amir, Abdi O. Shuriye, Ahmad F. Ismail 'The foundation of science and technology in view of Muhammad Abduh,' Asian Journal of Natural \& Applied Sciences 1, no. 2 (2012).

38. Yoginder Sikand, 'Reforming the Indian Madrassas: Contemporary Muslim Voices,' Forum for Peaceful Coexistence, Sri Lanka, 2016. Available at: https:// mffcoexist.wordpress.com/2016/05/14/reforming-the-indian-madrassascontemporary-muslim-voices/ (Accessed on: 17 April 2017).

39. For a paper about reforming Muslim learning by integrating present-day subjects with traditional education, see Abdul Karim Abdullah, 'Raising the Quality of Muslim Learning: Broadening of the Curriculum,' Islam and Civilisational Renewal 7, no. 3 (2016): 346-66.

40. Yahya Birt, 'The Message of Fazlur Rahman,' Association of Muslim Researchers, 2001. Available at: http://www.freerepublic.com/focus/fr/531762/ posts (Accessed on 24 April 2017).

41. Mohammad Hashim Kamali, 'Reading the Signs: The Qur'anic Perspective on Thinking,' Islam and Science 4, no. 2 (2006): 143.

42. Qur'an, 51:20-1.

43. Qur'an, 38:29.

44. Mohammad Hashim Kamali, 'Reading the Signs,'143.

45. Mehdi Hasan, 'Dawkins Is Wrong - Religion Is Rational,' Huffpost Politics 23 (2013). Available at: http://www.huffingtonpost.co.uk/mehdi-hasan/dawkinsis-wrong-religion-is-rational_b_2358000.html (Accessed on: 24 February 2017).

46. Mohammad Hashim Kamali, 'Reading the Signs,'145-6.

47. Mohammad Hashim Kamali, Principles of Islamic Jurisprudence (UK:The Islamic Texts Society, 2003), 13.

48. For a paper on reflective thought, see Abdul Karim Abdullah 'Strengthening Critical Thinking Skills Among Muslim Students,' Islam and Civilisational Renewal 1, no. 4 (2010): 649-65. 
49. Qur'an, 2:170, and 5:104.

50. Qur'an, 33: 67.

51. Mohammad Hashim Kamali 'Islam, Rationality And Science,' Islam and Science 1, no. 1 (2003): 128.

52. AbuSulayman, Crisis in the Muslim Mind, 45.

53. Mohd Kamal Hassan 'The Integration of Human Sciences and Revealed Knowledge in the KIRKHS,' IIUM at 25: The Path Travelled and The Way Forward, ed. Syed Arabi Idid (Kuala Lumpur: IIUM Press, 2009), 111-124.

54. 'Izz al-Din 'Abd al-Salam (d.1262), quoted in Mohammad Hashim Kamali 'Maqasid al-Shari'ah and Ijtihad as Instruments of Civilisational Renewal: A Methodological Perspective,' Islam and Civilisational Renewal 2, no. 2 (2011): 258-9.

55. For a brief account of efforts to Islamise present-day empirical disciplines, see Abdul Karim, 'Raising the Quality of Muslim Learning.'

56. Wahyudi, 'The Slogan 'Back to the Qur'an and the Sunna,' 2-3.

57. Barazangi, Nimat Hafez, Donald Malcolm Reid, Syed Rizwan Zamir, Dietrich Reetz, Joseph S. Szyliowicz, Akbar S. Ahmed and Anis Ahmad, 'Education,' in The Oxford Encyclopedia of the Islamic World. Available at: http://www. oxfordislamicstudies.com/article/opr/t236/e0212 (Accessed on: 26 Oct 2016).

58. Mohammad Hashim Kamali, 'Reading the Signs,'142.

59. For a treatment of taqlid in Muslim education, see Abdul Karim Abdullah 'Overcoming Taqlid in Muslim Institutions of Learning,' Islam and Civilisational Renewal 6, no. 1 (2015): 43-57.

60. Kamali, 'Maqasid al-Shari'ah and Ijtihad,' 259.

61. See Mohammad Hashim Kamali, The Middle Path of Moderation in Islam: The Qur'anic Principle of Wasatiyyah (Oxford: Oxford University Press, 2015).

62. Mervyn F. Bendle, review of 'The Closing of the Muslim Mind,' by Robert R. Reilly, National Observer 83, June - August 2010. Available at: http://www. nationalobserver.net/2010/83_6_book_reilly.htm (Accessed on: 19 April 2017)

63. Mohammad Hashim Kamali, 'Reading the Signs,'162.

64. AbuSulayman, Crisis in the Muslim Mind, 44. 